\title{
STUDIES ON NISIN PRODUCTION BY ISOLATED LACTOBACILLUS SPECIES IN AQUEOUS TWO-PHASE SYSTEM
}

\author{
Namita Singh* and S.K. Mandal*
}

\begin{abstract}
Isolated Lactobacillus sp. (from cheese whey) was examined for its ability to produce bacteriocin like nisin in submerged fermentation and aqueous two-phase system (ATPS) at $\mathrm{pH} 6.5,30^{\circ} \mathrm{C}$ for $18 \mathrm{~h}$ fermentation using M17S medium with $5 \%(\mathrm{v} / \mathrm{v})$ inoculum and the nisin yields were obtained $4500 \mathrm{JU} / \mathrm{m} /$ and $20216 \mathrm{U} / \mathrm{m} /$ where as biomass yields obtained $19.55 \mathrm{mg} / \mathrm{m} /$ and $31.88 \mathrm{mg} / \mathrm{m} /$ respectively. The maximum yield of nisin $(24800 \mathrm{JU} / \mathrm{ml})$ and biomoss $(22.49 \mathrm{mg} /$ $\mathrm{ml})$ were obtained in ATPS $\left(28 \% \mathrm{PEG}_{6000}\right.$ and $4 \% \mathrm{MgSO}_{4}, 7 \mathrm{H}_{2} \mathrm{O}$ with 5-times concentrated $\mathrm{M} 17$ medium containing $0.5 \%$ lactose as carbon source) under similar conditions.
\end{abstract}

Department of Biochemical Engg. and Food Technology, Harcourt Butler Technologicall Instifute, Kanpur-208002, India.Emoil-ranjeet_hbti@rediffmail.com 


\section{Introduction}

Presently, bacterial nisin is used in preservation of processed cheese spread and various canned foods (Broughton, 1990) to extend the self life of pasteurized milk and to control lactic acid bacteria in beer production (Taniguchi et al., 1994). It inhibits bacterial spore germination and growth of $\mathrm{Gram}(+)$ bacteria. This bioactive peptide, nisin which is active against Gram $(+)$ bacteria and has a molecular weight of $3354 \mathrm{Da}$ and composed of 34 amino acids (Kim, 1997). For this reason, it is widely used as a natural preservative (Vessoni Penna and Moraes, 2002).

Lactic acid bacteria exert lactic acid into the growth medium to the concentration which is inhibitory to their growth. Integration of product removal from the fermentation medium is a means to reduce the end product inhibition and thus increase the productivity (Dissing and Mattiasson, 1994). One such technique is the extractive fermentation using aqueous two-phase system (ATPS), which provides a biocompatible environment for the bacterial cells (Fan. Ouyang and Bai, 2000).

Lactobacillus sp. isolated from cheese whey in our laboratory has been shown to produce significant amount of a bacteriocin like nisin. In this study, several parameters such as phase components, growth temperafure, cultivation time, $\mathrm{pH}$, carbon sources, nitrogen sources and PEG of different molecular weights are investigated for the production and optimization of this bacteriocin by isolated Lactobacillus sp.

\section{Materials and Method}

\section{Bacterial strains}

Lactobacillus sp. isolated from cheese whey was used in this study for nisin production. Screening of antibacterial activity of the isolates was done using $B$. licheniformis MTCC 1483 and estimation of produced nisin activity was done by S. cremoris NCIM 2179 as test organism.

\section{Media and culture conditions}

Isolated Lactobacillus sp. was grown on MI7S medium containing ( $\mathrm{g} / \mathrm{l})$; peptone, 5 ; phytone, 5 ; yeast extract, 2.5 ; beef extract, 5 ; sucrose, 5 ; ascorbic acid, 0.5 ; disodium b-glycerophosphate, 19 and $1 \mathrm{ml}$ of $1.0 \mathrm{M} \mathrm{MgSO}_{4} .7 \mathrm{H}_{2} \mathrm{O}$ at $\mathrm{pH} 6.5$ and $30^{\circ} \mathrm{C}$ for $18-24 \mathrm{~h}$. 
ATPS medium was prepared by five times concentrated $\mathrm{M} 17 \mathrm{~S}$ (without sucrose and $\mathrm{MgSO}_{4} \cdot 7 \mathrm{H}_{2} \mathrm{O}$ l along with $28 \% \mathrm{PEG}_{6000}$ or $\mathrm{PEG}_{4000}$ and $4 \% \mathrm{MgSO}_{4} .7 \mathrm{H}_{2} \mathrm{O}$. Concentrated sucrose solution was sterilized separately and added before inoculation so as to avoid browning.

Isolation and maintenance of Lactobacillus sp. was done on MRS medium containing $(\mathrm{g} / \mathrm{l})$; peptone, 10; beef extract, 10 ; yeast extract, 5 ; glucose, 20; $\mathrm{K}_{2} \mathrm{HPO}_{4}$, 2; sodium acetate, 5 ; triammonium citrate, $2 ; \mathrm{MgSO}_{4} 7 \mathrm{H}_{2} \mathrm{O}, 0.2$; $\mathrm{MnSO}_{4} \mathrm{7H}_{2} 0,0.2$; agar, 20 , $\mathrm{pH} 6.2-6.6$, was sterilized at $121^{\circ} \mathrm{C}$ for 20 min and after cooling, incubated at $30-32^{\circ} \mathrm{C}$ for 24 to $48 \mathrm{~h}$.

Maintenance of $S$. cremoris was also done on MRS medium where as medium for $B$. licheniformis contains $(\mathrm{g} / \mathrm{l})$; corn starch, 10; yeast extract, 2; peptone, 5; $\mathrm{MgSO}_{4} .7 \mathrm{H}_{2} \mathrm{O}, 0.5 ; \mathrm{KH}_{2} \mathrm{PO}_{4}, 0.5 ; \mathrm{NaCl}, 1.5 ; \mathrm{CaCl}_{2}, 1.5 ;$ agar, $20 ; \mathrm{pH} 7$ and incubated at $37^{\circ} \mathrm{C}$ for $24 \mathrm{~h}$.

\section{Isolation of bacterial strains}

Lactic acid bacteria (LAB) are known to occur in milk products, meat products, fruits and vegetables. Samples of curd, cheese whey, spoiled milk and cabbage leaves were collected from local market, brought to laboratory within $3 \mathrm{~h}$ of collection and immediately used for isolation purpose. $1 \mathrm{ml}$ of each sample was mixed in $10 \mathrm{ml}$ sterile distilled water and several dilutions such as $10^{-1}, 10^{-2}$, $10^{-3}$ and $10^{-4}$ were done separately with $15 \mathrm{ml} \mathrm{MRS}$ agar medium for plating and incubated at $32^{\circ} \mathrm{C}$ for $48 \mathrm{~h}$. Pink colored distinct colonies were isolated and grown on the fresh MRS agar medium to obtain pure culture.

\section{Selection of bacterial strains on the basis of their antimicrobial activity.}

The antibacterial activity of the isolated culture of $L A B$ was detected, following the 'agar spot' test using B. licheniformis as a test organism (Lewus and Montville, 1991). Among 10 different isolates, the antibacterial activity was determined on the basis of zone of inhibition. The isolated bacterial strain, producing maximum inhibition zone diameter (mm), was used for further studies (Sholera et al., 1998).

\section{Inoculum preparation and cultivation}

Isolated Lactobacillus sp. was inoculated into $20 \mathrm{ml}$ of the cultivation medium (MI7S) in a $100 \mathrm{ml}$ Erlenmeyer flask and incubated at $30^{\circ} \mathrm{C}$ and $180 \mathrm{rpm}$ for $24 \mathrm{~h}$. A fresh culture of actively growing cells was always used as the inoculum. Fermentations were carried out in $250 \mathrm{ml}$ Erlenmeyer flask containing $50 \mathrm{ml}$ 
production media along with $5 \%(\mathrm{v} / \mathrm{v})$ inoculum. The flasks were incubated at $30^{\circ} \mathrm{C}$ and $180 \mathrm{rpm}$ for $18 \mathrm{~h}$ without $\mathrm{pH}$ control. Samples were withdrawn at regular interval and analyzed for growth and nisin activity.

\section{Growth determination}

The fermentation broth was centrifuged at $8000 \mathrm{rpm}$ for $10 \mathrm{~min}$ and the cells were washed twice with saline $(0.9 \% \mathrm{NaCl})$ and dried for $90 \mathrm{~min}$ at $105^{\circ} \mathrm{C}$. The cells grown were expressed in terms of $d r y$ weight basis $(\mathrm{mg} / \mathrm{ml})$.

\section{Nisin activity determination}

For estimating nisin activity, samples from both the phases were collected and $\mathrm{pH}$ was adiusted to 2.0 with a few drops of $5.0 \mathrm{M} \mathrm{HCl}$. The samples were then heated in boiling water for $10 \mathrm{~min}$, cooled to $30^{\circ} \mathrm{C}$ and appropriate dilutions (2 to 5 times) were made with $0.02 \mathrm{M} \mathrm{HCl}$ (Kim et al., 1997). The nisin activity of the above diluted samples (clear supernatant) was determined by agar diffusion method (Bioassay) using S. cremoris NCIM 2179 as a test organism (Beach, 1952).

A standard curve $(10$ to $10,000 \mathrm{IU} / \mathrm{ml}, 900 \mathrm{IU}=1 \mathrm{mg}$ of pure nisin) was made using a stock solution of $10,000 \mathrm{lU} / \mathrm{ml} \mathrm{nisin} \mathrm{ml}^{-1}$. The latter was prepared by dissolving $55.55 \mathrm{mg}$ of nisin into $5 \mathrm{ml} 0.02 \mathrm{~N} \mathrm{HCl}$. The activity of nisin from samples was determined and expressed in international units per $\mathrm{ml}\left(10^{\circ}\right.$ to $\left.10^{4} \mathrm{IU} / \mathrm{m} \mathrm{l}\right)$. Each assay was performed in duplicate (Pongtharangkul and Demirci, 2004).

\section{Results and Discussion}

This paper reports on the potential use of aqueous two-phase system for cultivation of isolated Lactobacillus sp. to produce nisin.

\section{Selection of the isolated strain}

Only three strains $I_{1}, I_{2}$ and $l_{3}$ among ten isolated bacterial strain showed noticeable antibacterial activity (Table 1).

Of these three isolates, $\mathrm{l}_{2}$ obtained from cheese whey gave maximum nisin activity of $3090 \mathrm{IU} / \mathrm{ml}$ and biomass of $16.50 \mathrm{mg} / \mathrm{ml}$ in Mi TS broth. However, $I_{3}$ from cabbage leaves showed optimum activity of $1080 \mathrm{IU} / \mathrm{ml}$ and biomass of $12.90 \mathrm{mg} / \mathrm{ml}$. Isolate $\mathrm{I}_{1}$ from spoiled milk gave minimum nisin activity of 
$560 \mathrm{JU} / \mathrm{ml}$ and biomass of $9.60 \mathrm{mg} / \mathrm{ml}$. Thus the further experiments were carried out using isolate $\mathrm{I}_{2}$ only.

Selection of salt to suit aqueous two-phase system formation and cell growth

Lactic acid bacteria can tolerate high osmotic pressure, using this property; we added various salts $(5 \%)$ in $\mathrm{Ml} 7$ medium to test their effects on cell growth. Results are summarized in Table 2.

The data in the Table 2 indicate that out of four different salts tested, $\mathrm{MgSO}_{4} .7 \mathrm{H}_{2} \mathrm{O}$ allowed the maximum growth of isolated Lactobacillus $\mathrm{sp}$. $(12.87 \mathrm{mg} / \mathrm{ml})$ whereas the control representing the MITS broth (without any added salt) produced the maximum growth of isolated Lactobacillus sp. $(27.95 \mathrm{mg} / \mathrm{ml})$ along with phase separation. $\mathrm{Kpi}^{+}$also resulted in better growth of bacterial cells as compared to other salts, but it was enable to create phase separation when added to ATPS media. Since $\mathrm{MgSO}_{4} .7 \mathrm{H}_{2} \mathrm{O}$ was the only salt in $\mathrm{Ml} 7 \mathrm{~S}$ medium for the maximum cell growth and hence it is concluded that $\mathrm{MgSO}_{4} \cdot 7 \mathrm{H}_{2} \mathrm{O}$ is the best salt to be used to form an ATPS with PEG.

\section{Variation of salł concentration $\left(\mathrm{MgSO}_{4} .7 \mathrm{H}_{2} \mathrm{O}\right)$}

The effects of $\mathrm{MgSO}_{4} \cdot 7 \mathrm{H}_{2} \mathrm{O}$ concentrations ( 3.5 to $8 \% \mathrm{w} / \mathrm{v}$ ) on cell growth were examined employing $\mathrm{M} 17 \mathrm{~S}$ broth at initial $\mathrm{pH} 6.5,30^{\circ} \mathrm{C}$ and $180 \mathrm{rpm}$ for $18 \mathrm{~h}$.

The observed growth of cells is given in Table 3 .

The results from Table. 3 indicate that growth of cells increased gradually with increasing salt concentration from 3.5 to $4 \%$ and maximum cell growth $(20.60 \mathrm{mg} / \mathrm{ml})$ attained with $4 \%$ salt concentration. On further, increasing the salt concentration. (from $4-8 \mathrm{w} / \mathrm{v} \%$ ) the biomass yield decreased gradually and it reached to $5.21 \mathrm{mg} / \mathrm{ml}$ with $8 \%$ salt concentration. Thus result indicates that $4 \% \mathrm{MgSO}_{4} \cdot 7 \mathrm{H}_{2} \mathrm{O}$ was suitable for maximum cell growth and nisin production by aqueous two-phase system. Phase separation was also visible with $4 \%$ salts concentration.

\section{Effect of PEG molecular weight on cell growth and nisin production}

The isolated Lactobacillus sp. grown with $28 \% \mathrm{PEG}_{4000}$ or $\mathrm{PEG}_{6000}$ and $4 \%$ $\mathrm{MgSO}_{4} .7 \mathrm{H}_{2} \mathrm{O}$ in ATPS media at initial pH $6.5,30^{\circ} \mathrm{C}$ and $180 \mathrm{rpm}$ for $18 \mathrm{~h}$ and the results are given in Table 4. 
Table 1. Comparison of nisin activity and cell growth obtained from isolated strains $I_{1}, I_{2}$ and $I_{3}$

\begin{tabular}{|c|c|c|}
\hline Priomass Isolate & yield $(\mathrm{mg} / \mathrm{ml})$ & Nisin activity $(\mathrm{IU} / \mathrm{ml})$ \\
\hline$I_{1}$ & 9.60 & 560 \\
\hline$I_{2}$ & 16.50 & 3090 \\
\hline$I_{3}$ & 12.90 & 1080 \\
\hline
\end{tabular}

Table 2. Effect of various salts on bacterial cell growth, isolated Lactobacillus sp.

\begin{tabular}{|c|c|c|}
\hline Salts & Concentration $(w / w)$ & Biomass (mg/ml) \\
\hline $\mathrm{NaCl}$ & $5 \%$ & 4.021 \\
\hline $\mathrm{MgSO}_{4} \cdot 7 \mathrm{H}_{2} \mathrm{O}$ & $5 \%$ & 12.87 \\
\hline $\mathrm{MgCl}_{2} \cdot 6 \mathrm{H}_{2} \mathrm{O}$ & $5 \%$ & 2.60 \\
\hline${ }^{*} \mathrm{Kpi}^{+}$ & $5 \%$ & 6.56 \\
\hline${ }^{* *} \mathrm{Control}$ & 0 & 27.95 \\
\hline
\end{tabular}

${ }^{*} \mathrm{~K}_{2} \mathrm{HPO}_{4}+\mathrm{KH}_{2} \mathrm{PO}_{4}[1: 1]$

** MITS broth

Table 3. Effect of salt on phase separation and growth of isolated Lactobacillus sp.

\begin{tabular}{|c|c|}
\hline $\begin{array}{c}\text { Concentration of } \\
\mathrm{MgSO}_{4} .7 \mathrm{H}_{2} \mathrm{O}(1 \% \mathrm{w} / \mathrm{v})\end{array}$ & Biomass (mg/ml) \\
\hline 3.5 & 12.20 \\
4.0 & 20.60 \\
4.5 & 18.10 \\
6 & 9.66 \\
8 & 5.21 \\
\hline
\end{tabular}


From the data given in Table 4 it is found that biomass increases with increasing the molecular weight of PEG, since maximum biomass of isolated Lactobacillus sp. was obtained with $\mathrm{PEG}_{6000}(31.80 \mathrm{mg} / \mathrm{ml})$ as compared to $\mathrm{PEG}_{4000}$ $(26.65 \mathrm{mg} / \mathrm{ml})$.

Nisin activity was also found to be affected by PEG molecular weight, since no phase separation was obtained with $P E G_{4000}$ due to lower molecular weight $(4000 \mathrm{Da})$. Nisin activity was 20216 and $780 \mathrm{lU} / \mathrm{ml}$ with $\mathrm{PEG}_{6000}$ and $\mathrm{PEG}_{4000}$ respectively. It is found that nisin concentration was positively correlated with the molecular weight of PEG as the biomass yield and nisin production were increased with increasing molecular weight of PEG.

\section{Nisin production by submerged fermentation and aqueous two-phase system (ATPS)}

The fermentation was carried out separately in MI7S broth and ATP media using freshly grown isolated Lactobacillus cells at initial pH $6.5,30^{\circ} \mathrm{C}$ and 180 $\mathrm{rpm}$ for $18 \mathrm{~h}$ and the results obtained are indicated in Tables 5 and 6 respectively for submerged fermentation and ATPS.

Fermentation results from Table 5 and Table 6 indicate that maximum nisin yield of $20216 \mathrm{JU} / \mathrm{ml}$ was attained with isolated strain in ATPS, where as this yield was $4500 \mathrm{IU} / \mathrm{ml}$ in submerged fermentation. Similarly, bacterial cell growth was also higher in ATPS (31.67 mg/ml) as compared to submerged fermentation (19.55 $\mathrm{mg} / \mathrm{ml})$.

\section{Effect of $\mathrm{PEG}_{6000}$ concentration on nisin production}

The effects of different concentration of $\mathrm{PEG}_{6000}$ on cell growth and nisin production were examined employing ATPS media with $4 \% \mathrm{MgSO}_{4} .7 \mathrm{H}_{2} \mathrm{O}$ and different concentration ( $11 \%-30 \%$ ) of $\mathrm{PEG}_{6000}$ at initial $\mathrm{pH} 6.5,30^{\circ} \mathrm{C}$ and $180 \mathrm{rpm}$ for 18 h. The results are indicated in Table 7.

Results from Table 7 indicate that with increasing concentration of $P E G_{6000}$ from 11 to $28 \%$, biomass and nisin activity increased gradually but on further increasing $\mathrm{PEG}_{6000}$ concentration above 28 to $30 \%$, there was a sharp decrease in biomass yield and nisin activity. The maximum nisin activity of $(20216 \mathrm{lJ} / \mathrm{ml})$ was attained with $28 \% \mathrm{PEG}_{6000}$ with clear phase separation where as moderate activities were obtained with $11 \%-18 \%$ PEG $_{6000}$ but there was no phase separation observed. The amount of nisin produced was positively correlated with concentration of $P E G_{6000}$ and the ratio of the top phase to bottom phase. The yield of nisin was 
maximum when the volume of top phase was bigger that that of the bottom phase which was obtained with $28 \% \mathrm{PEG}_{6000}$ and $4 \% \mathrm{MgSO}_{4} \cdot 7 \mathrm{H}_{2} \mathrm{O}$.

\section{Effect of $\mathrm{pH}$ on nisin production}

Several experiments were performed to study the effect of $\mathrm{pH}$ values on nisin production by the strain under investigation in ATPS at $30^{\circ} \mathrm{C}$ and $180 \mathrm{rpm}$ for $18 \mathrm{~h}$. The $\mathrm{pH}$ values of the production media were taken in range of $4-8$. The results are given in Table 8 .

Table 4. Effect of polyethylene glycol (PEG) molecular weight on nisin production

\begin{tabular}{|l|c|c|c|c|c|c|c|}
\hline \multicolumn{2}{|c|}{$\mathrm{PEG}_{4000}$} & \multicolumn{3}{|c|}{$\mathrm{PEG}_{6000}$} \\
\hline $\begin{array}{l}\text { Final } \\
\mathrm{pH}\end{array}$ & $\begin{array}{c}\text { Biomass } \\
\text { yield } \\
(\mathrm{mg} / \mathrm{mll})\end{array}$ & $\begin{array}{c}\text { Nisin } \\
\text { activity } \\
\text { a(lU/ml) }\end{array}$ & $\begin{array}{c}\text { Final } \\
\mathrm{pH}\end{array}$ & $\begin{array}{c}\text { Biomass } \\
\text { yield } \\
(\mathrm{mg} / \mathrm{ml})\end{array}$ & \multicolumn{3}{|c|}{ Nisin activity (IU/ml) } \\
\cline { 5 - 8 } & & $\begin{array}{c}\text { Top } \\
\text { phase }\end{array}$ & $\begin{array}{c}\text { Bottom } \\
\text { Phase }\end{array}$ & $\begin{array}{c}\text { Average } \\
\text { activity }\end{array}$ \\
\hline 5.81 & 10.64 & 780 & 5.60 & 31.80 & 14125 & 28183 & 20216.8 \\
\hline
\end{tabular}

Table 5. Nisin production by isolated Lactobacillus sp. using submerged fermentation

\begin{tabular}{|c|c|c|}
\hline Final $\mathrm{pH}$ & Biomass yield $(\mathrm{mg} / \mathrm{ml})$ & Nisin activity $(\mathrm{IU} / \mathrm{ml})$ \\
\hline 5.94 & 19.55 & 4500 \\
\hline
\end{tabular}

Table 6. Nisin production by isolated Lactobacillus sp. using ATPS

\begin{tabular}{|c|c|c|c|c|}
\hline \multirow[t]{2}{*}{ Final $\mathrm{pH}$} & \multirow{2}{*}{$\begin{array}{c}\text { Biomass } \\
\text { yield (mg/ml) }\end{array}$} & \multicolumn{3}{|c|}{ Nisin activity $(1 \mathrm{U} / \mathrm{ml}$} \\
\hline & & Top phase & Bottom phase & Average \\
\hline 5.60 & 31.67 & 14125 & 28183 & 20216 \\
\hline
\end{tabular}


Data from Table 8 indicate that with increasing $\mathrm{pH}$ value from 4 to 6.5 , the nisin activities as well as biomass yields increased continuously However, the biomass yield $(31.80 \mathrm{mg} / \mathrm{ml})$ and nisin production $(20216 \mathrm{IU} / \mathrm{ml})$. by isolated Lactobacillus sp. were optimum at $\mathrm{pH} 6.5$. On further increasing the $\mathrm{pH}$ value above 6.5 there was a sharp decline in both the nisin activity and biomass yield.

\section{Effect of lactose and sucrose as carbon sources on nisin production in ATPS}

Experiments have done to find the effect of lactose and sucrose on the biomass yield and nisin production in ATPS with $28 \%, \mathrm{PEG}_{6000}$ and $4 \% \mathrm{MgSO}_{4} .7 \mathrm{H}_{2} \mathrm{O}$ at initial $\mathrm{pH} 6.5,30^{\circ} \mathrm{C}$, and $180 \mathrm{rpm}$ for $18 \mathrm{~h}$ fermentation. The results are given in Table 9.

From the Table 9 it is evident that sucrose promoted the growth of isolated Lactobacillus sp. (biomass yield $31.67 \mathrm{mg} / \mathrm{ml}$ ) whereas lactose gave the maximum yield of nisin $(24800 \mathrm{IU} / \mathrm{ml})$. Control represents the ATPS medium without any carbon source.

\section{Conclusions}

Experimental data on the production of active bacteriocin like nisin have shown that its production is severely affected by various factors. The effects of phase component on phase separation in ATPS have also studied. These studies have shown that it is imperative to have an accurate quantification method to distinguish between growth promoting factors and those that actually affect nisin production. A comparison between submerged fermentation and ATPS indicates that ATPS is suitable for nisin production since the nisin yield is obtained $20216 \mathrm{lU} / \mathrm{ml}$, which is approximately 4 -folds to that of submerged fermentation $(4500 \mathrm{JU} / \mathrm{ml})$ with isolated Lactobacillus sp. Further, experimental results signify that $\mathrm{MgSO}_{4} .7 \mathrm{H}_{2} \mathrm{O}$ at a concentration of $4 \%(\mathrm{w} / \mathrm{v})$ is suitable for cell growth (Table 3) and phase separation (Table 7).

On the variation of $\mathrm{PEG}_{6000}$ concentration it is found that maximum nisin activity is attained $20216 \mathrm{JU} / \mathrm{ml}$ with $28 \%$ PEG by isolated Lactobacillus sp. Phase separation is also visible with this composition hence, it is concluded that $28 \%$ $\mathrm{PEG}_{6000}$ and $4 \% \mathrm{MgSO}_{4} .7 \mathrm{H}_{2} \mathrm{O}$ is suitable for phase separation and nisin production in ATPS (Table 7). It is also found that $0.5 \%$ lactose along with $\mathrm{M} 17$ medium in ATPS gave maximum yield of nisin $24800 \mathrm{lU} / \mathrm{ml}$ and similar conditions. 
Table 7 .

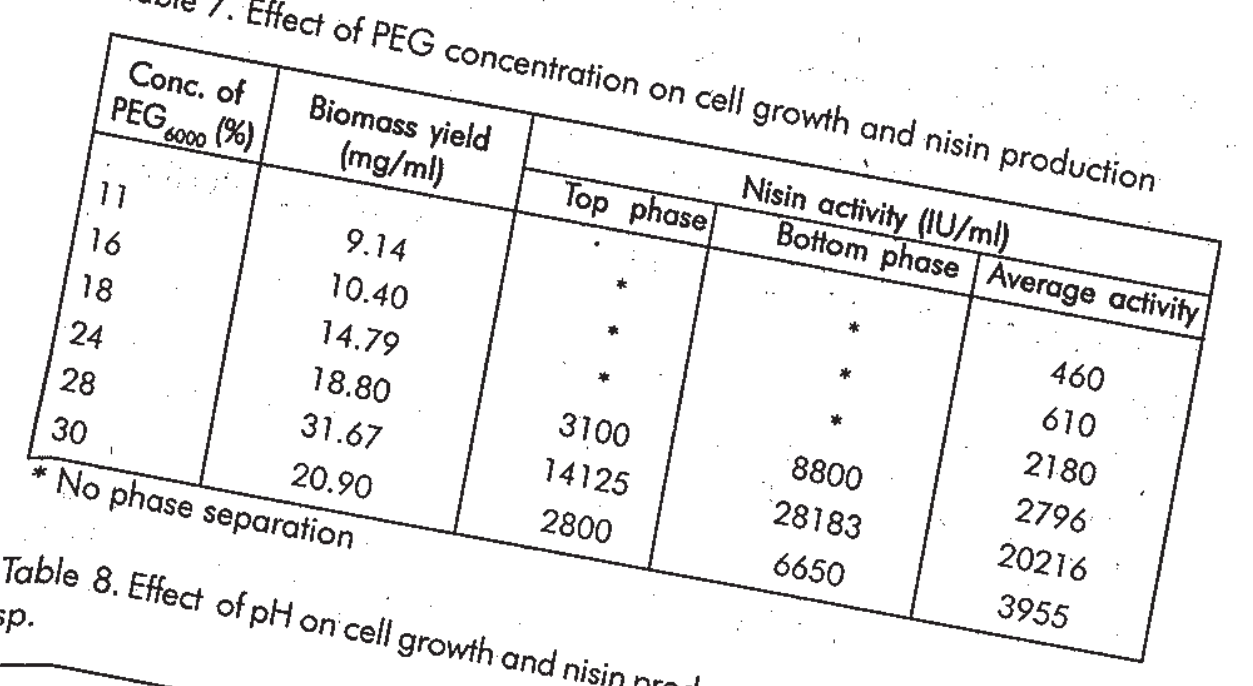
sp.

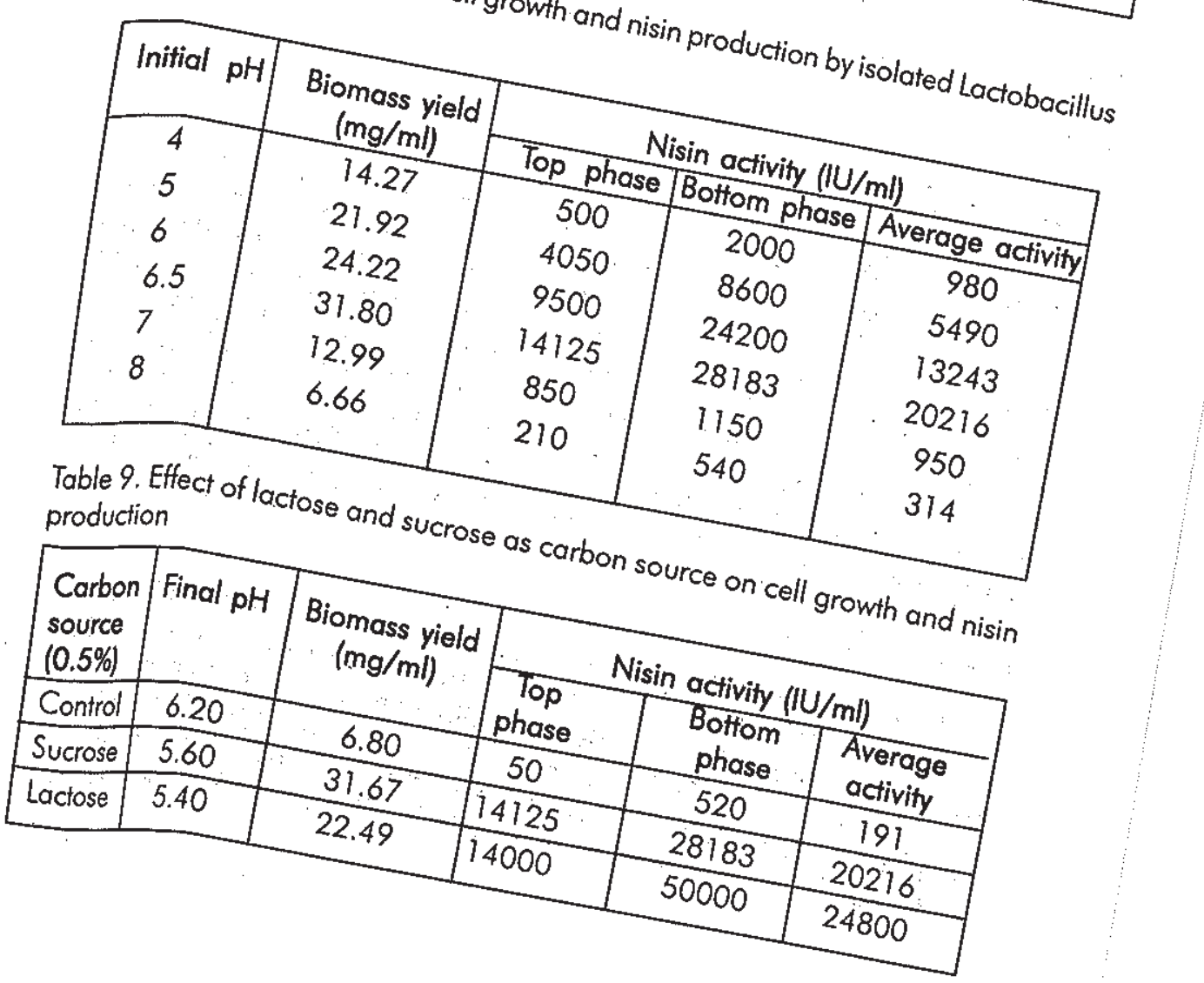


Studies on the variation of PEG molecular weight using. $\mathrm{PEG}_{6000}$ and $\mathrm{PEG}_{4000}$ and the results indicate that there exist a positive correlation between the PEG molecular weight and nisin production. Phase separation is also visible with higher molecular. weight of PEG (Table 4).

Thus the present studies on nisin production conclude that aqueous two-phase system provides a biocompatible environment for bacterial cells and a potential process for the extractive cultivation where the cells are confined to one phase and product in other phase. It is possible to cultivate the cells and extract lactic acid to reduce growth inhibition and enhance nisin accumulation using ATPS. This provides a technological solution to reduce end product inhibition. In view of attractive applications of nisin as preservative for food and feed items, these factors are to be considered for the design of bioprocess for efficient production of nisin.

\section{References}

1. Beach AS (1952) A agar diffusion method for the assay of nisin. $J$ Gen Microbiol 6:60-63.

2. Broughton JB (1990) Nisin and its uses as a food preservative. Food Technol 44: 100-117.

3. Chandrapati S and O'Sullivan DJ (1998) Procedure for quantifiable assessment of nutritional parameters influencing nisin production by Lactococcus lactis subsp lactis. J Biotech 63: 229. 233.

4. Dissing U and Mattiasson B (1994) Cultivation of Lactococcus lactis in a polyelectrolyte neutral polymer aqueous two-phase system. Biotechnol Lett $16: 333-338$.

5. Fan Ouyang $\mathrm{CL}$ and Bai $\mathrm{J}(2000)$ Extractive cultivation of Lactococcus lactis using a polyethylene glycol/ $\mathrm{MgSO}_{4} .7 \mathrm{H}_{2} \mathrm{O}$ aqueous twophase system to produce nisin. Biotechnol Left 22:843847.

6. Kim WS (1997) Nisin production by Lactococcus lactis using two-phase batch culture. Lett in Appl Microbiol 25:169-171.

7. Kim WS Hall RJ and Dunn NW (1997a) The effect of nisin concentration and nutrient depletion on nisin production of Lactococcus lactis. Appl Microbiol Biotechnol 48:449-453.

8. Lewus CB and Montville TJ (1991) Defection of bacteriocins produced by lactic acid bacteria. $J$ Microbiol Meth 13:145-150.

9. Pongtharangkul T and Demirci A (2004) Evaluation of agar diffusion bioassay for nisin quantification. Appl Microbiol Biotechnol 65(3):268-272.

10. Sarkar PK and Baneriee $S$ (1996) Antibacterial activity of lactic acid bacterial isolates obtained from natural habitates. J Food Sci Technol 33:231-233

11. Sholera Z Stefanova $S$ and ChiperaV (1998) Screening of antimicrobial activities among Bulgarian Lactobacillus Strain. J of Cult Collec 2: 15-20. 
12. Taniguchi M Hoshino K Urasaki $H$ and Fujii $M(1994)$ Continuous production of an antibiotic polypeptide (nisin) by Lactococcus lactis using a bioreactor coupled to a microfiltration module. J Ferment Bioengg 77:704-708.

13. Vesoni Penna TC and Moraes DA (2002) Optimization of nisin production by Lactococcus lactis. Appl Bioch Biotech 98-100: 775-789. 